Volume and Issues Obtainable at Center for Sustainability Research and Consultancy

Journal of Accounting and Finance in Emerging Economies

ISSN: 2519-0318 \& ISSN (E): 2518-8488

Volume 7: Issue 2 June 2021

Journal homepage: www.publishing.globalcsrc.org/jafee

\title{
Impact of Corporate Governance on the Cost of Capital: Empirical Evidence from the Non-Financial Sector of Pakistan
}

*Muhammad Bilal Ijaz, Department of Management Sciences, Shaheed Zulfiqar Ali Bhutto Institute of Science and Technology, Islamabad, Pakistan

Muhammad Naveed, Department of Management Sciences, Shaheed Zulfiqar Ali Bhutto

Institute of Science and Technology, Islamabad, Pakistan

Hassan Raza, Pakistan Military Accounts Department, Rawalpindi

*Corresponding author's email: bilal.ijaz@uog.edu.pk

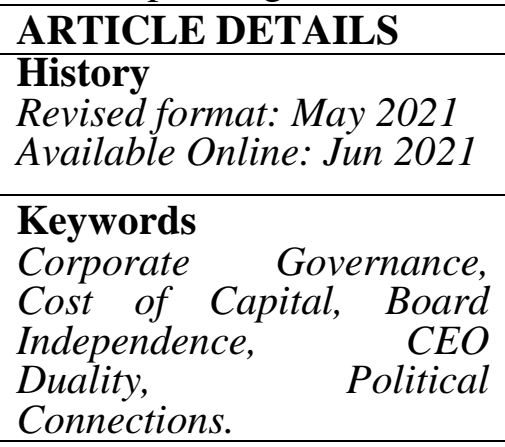

JEL Classification

M40, M41

\section{OPEN $\rightarrow$ ACCESS}

ABSTRACT

Purpose: The study looked at the effect of corporate governance on the cost of capital of firms in Pakistan's non-financial sector.

Design/Methodology/Approach: The study sample is comprised of balanced data set of 175 non-financial companies listed on the Pakistan Stock Exchange between 2008 and 2018. The study used the dynamic panel GMM estimator technique.

Findings: The findings revealed that an increase in the number of directors, board independence, CEO duality, and inflation negatively influence the cost of capital. On the other hand, the increase in institutional holdings increased the cost of capital. In addition, it is discovered that board committees, political connections, and economic growth do not affect the cost of capital

Implications/Originality/Value: When board size, CEO duality, board independence, and inflation increased, the cost of capital decreased in Pakistan's non-financial sector. Furthermore, board committees, political connections, company leverage, and economic growth do not affect the cost of capital in Pakistan's non-financial sector. In comparison, an increase in institutional shareholding increased the cost of capital in Pakistan's nonfinancial sector.

(C) 2021, The authors, under a Creative Commons AttributionNon Commercial 4.0

Recommended citation: Ijaz, M. B., Naveed, M. and Raza, H. (2021). Impact of Corporate Governance on the Cost of Capital: Empirical Evidence from the Non-Financial Sector of Pakistan. Journal of Accounting and Finance in Emerging Economies, 7 (2), 483-495.

\section{Introduction}

With two significant events in the late nineteenth century, the phrase "corporate governance" came into use. First, in Brazil, Russia, and Asia, the 1998 wave of financial crises worsened the worldwide economic situation. Second, following 2001, many self-inflicted problems, including Satyam Computers and Enron scandals, further weakened the global financial system. However, 
those above are the significant reasons why corporate governance (GC) has emerged as the primary concern for global sustainable growth (Becht, Bolton, \& Roell, 2002). Good governance is essential to improve the corporation's performance, protect shareholders' rights, and create an investment and economic growth (Braga-Alves \& Shastri, 2011). The firms with a weak corporate governance structure face severe agency problems because of the gaining of management's benefits irrespective of maximizing shareholders' wealth (Core, Holthausen, \& Larcker, 1999). The corporate failures resulting from weak governance systems need improvement and restructuring of corporate governance. Failure in stopping accounting fraud is a question mark regarding the governance rules and regulations (Sun, Stewart, \& Pollard, 2011).

The agency problem indicates that the directors are more concerned with their resources rather than the resources of others (Letza, Sun, \& Kikbride, 2004). According to the agency theory, the fundamental objective of corporate governance is to ensure that managers (agents) behave in the interests of the shareholders. It is also contended that the observing part of overwhelming investors and independent executives can conceivably alleviate management's self-serving conduct and enhance firm value (Jenses \& Meckling, 1976; Shleifer \& Vishny, 1997). However, corporate governance systems are different worldwide, so stakeholders believe that there should be a mechanism that minimizes agency issues. Hence, corporate governance is maintained for supervising management and communicates necessary information to the shareholders to hold management liable for the shareholders' wealth because, in such a way, his eir actions (AlMalkawi \& Pillai, 2012). In addition to this, stewardship theory also states a robust association between an organization's performance and the satisfaction of shareholders. A steward safeguards and maximizes the shareholders' wealth because his efficacy is enhanced in such a way.

Controlling shareholders and management are prevented from grabbing cash flows and infringing on the rights of minority shareholders by good corporate governance standards. As corporate governance quality increases, investors' trust in the firm grows. Increasing investor confidence enables the company to acquire more money at a lower cost (La Porta et al., 2002). Good corporate governance helps companies to save capital expenses, increase financing alternatives and liquidity, and get more capital market money (Ztürk \& Demirgüneş, 2008). In addition, corporate governance rules decrease the risks to investors by making more private information publicly available to companies and making it easy for companies to get capital at a cheaper cost; (Ashbaugh et al., 2004). However, virtually lacking is research on corporate governance's influence on capital costs ( $\mathrm{Rad}, 2014$ ). However, in earlier studies (for instance Ujunwa, 2012; Yang \& Zhao, 2014; Mishra \& Kapil, 2017; Bhatt \& Bhatt, 2017; Mir \& Nishat, 2004; Mehar, 2005; Javid \& Iqbal, 2008; Ali,Shah \& Butt,2009; Ahmed \& Javed, 2010; Yasser, 2011; Tariq \& Abbas, 2013) the effect of corporate governance on company performance improvement was explored. The results of the study stream failed to generate consistent and systematic data to establish an optimal governance structure.

In contrast, relatively few researchers have examined the relationship among corporate governance and capital costs for Pakistani companies (Butt \& Hasan, 2009; Rehman et al., 2010). Butt and Hasan (2009) examined the impact of board size, CEOs' duality, leverage, and board composition on the cost of capital, and inconsistent results are revealed. Ali, Shah and Butt (2009) also examined the effect on capital costs of corporate governance and established the links to the restricted variables of corporate governance being investigated, including board structure and ownership.

Almaqtari et al. (2020) findings also revealed that research in developing countries with samples after 2015 is scarce. Furthermore, the results indicated that there is much conceptually similar research, with the majority of them use descriptive statistics or simple regression analysis. In addition, previous research (Butt \& Hasan, 2009; Afza \& Mirza, 2011; Tariq \& Abbas, 2013) 
examined fewer companies. The present analysis makes use of balanced data from 2008 to 2018, whereas previous studies made use of imbalanced data from a shorter time range. Consequently, this study analysis is more comprehensive in terms of sample size and period than earlier research.

\section{Literature Review \\ Board size}

More precisely, it has been claimed that larger boards may increase the cost of managerial activities, decreasing the firm's value and perhaps raising the cost of capital (Yawson, 2006). The size of a board of directors of a firm has a negative link with its capital costs, the theory of the dependence on resources shows. Goodstein et al. (1994) suggested that greater board members might enhance business value through access to essential resources. Likewise, it is believed that greater board members may draw from experienced and skilled managers and make superior judgments. However, between board size and capital costs, there is a negative correlation. It shows that companies with big boards in Pakistan might suffer cheaper capital expenditures than those with smaller boards (Arslan \& Abidin, 2019).

H1: Board size has negative capital cost relationships.

\section{Board independence}

Ashbaugh et al., (2004) state that the cost of capital has a negative attachment to the board's independence, the share of the shareholder board, the number of shares held by directors, and the executive authority as a proxy for the number of shareholding rights.

Several studies were also conducted to analyze the impact on the capital expenses of independent directors. , there is a negative connection between the cost of capital and the board's independence (Ashbaugh et al., 2004). Different studies examine the influence on the cost of capital of external directors. However, the results of these studies demonstrate inconsistent and confusing conclusions about the connection between external managers, corporate performance, and capital costs. Mirsharafoddini et al. (2012), investigate the link between the independent board and the cost of capital of Tehran stock exchanges' between 2005 and 2011. The results showed that the independence of the board and the cost of capital were substantially beneficial. Bradley and Chen (2015), examined the board's independence and cost of capital from 2002 to 2006 and revealed that board independence would reduce capital costs in the event of aggressive credit or reduced leverage conditions.

On the other hand, it boosts loan costs in the case of bad credit or increased leverage. Independent board of directors establish organizational rules that increase company risk. With growing agency conflicts between these two groups, independent board directors perform better for stockholders but are more expensive for bondholders.

$\mathrm{H} 2$ : The board independence has a negative relation with capital cost.

\section{CEO Duality}

For the duality of CEO, if one person holds two roles simultaneously in the business, the single person being CEO and holding chair of the board at the same time (Tuggle et al., 2010). Dependence on the notion of the resource may also reduce the quantity and diversity of resource linkages outside the organization by becoming chairperson or board member. As a consequence, a solid dualistic leadership structure minimizes the cost of capital (Doan \& Acar, 2020).

H3: The duality of CEO has a considerable effect on capital costs.

\section{Board committees}

The previous study has shown that management committees are essential members of the board 
of directors of a business, affecting the company's capital cost. Kajanathan (2012) revealed a substantial positive relationship among board committees and the cost of capital in developingcountry firms. Awan et al. (2011) suggested a strong relationship among the board committee and the cost of capital. Whereas Bulathsinhalage and Pathirawasam (2017) found an insignificant relationship with the cost of capital.

H4: Board committees have a significant influence on capital cost.

\section{Political Connection}

Political connections are connected to the political involvements of shareholders, senior executives, and the government. Others link it with political contributions to campaigns or parties. Others continue to link political ties to concerns about government policies and operations. Appointing people with political ties to company boards is one example of such relationships (Houston et al., 2014). The consequence is monitoring the probable effect of political business links on performance and funding expenses by accountants, academics, and lawmakers (Houston et al., 2014; Wong \& Hooy, 2018).

H5: The cost of capital is significantly affected by political connections

\section{Leverage}

According to Ilyas and Jan(2017), leverage the insignificant relationship with the cost of capital But, because of the increased danger of failed bankruptcy resulting from high debt levels, investors expect higher capital costs.

H6: Leverage impacts the cost of capital substantially.

\section{Firms Size}

Contrasting small organizations, large corporations are more differentiated, which lessens the company's potential risk and capital costs Botosan and Plumlee (2005). Nevertheless, the corporation's scale can be linked to better governance because of its complicated procedures, increased control and policy expenses, and the cost of execution of code and agency issues (Beiner et al., 2006). Large companies may have a lower external cost of capital or better business value, according to Botosan (1997). According to Ilyas and Jan (2017), scale is inversely but strongly linked to the cost of capital. Small companies have fewer options for capital financing. As relative to multinational corporations, the cost of capital is high.

H7: The size of companies has a major influence on capital cost

\section{Institutional Shareholding}

It also has a substantial influence on capital costs. Researchers have found that institutional investors monitor and enhance CG transparency (Barako et al., 2006). Monitoring is beneficial in reducing disagreements among investors and directors, according to Jensen and Meckling (1976). Researchers (like Solomon, 2010; Chung \& Zhang, 2011) state that institutional investors are more motivated to maintain investing, especially when it is very costly for the company. As a result, they ensure that senior management and shareholders are held to a high standard of responsibility (Hudaib, 2006; Aggarwal et al., 2011). The connection between institutional investors and costs of capital has only been investigated in a few cases. Bhojraj and Sengupta (2003) have analyzed the impact of institutional ownership on the cost of capital by using a sample of over 1,000 bond issuances from 1991. They found a negative connection between capital costs and institutional ownership. Similarly, from 1999 to 2001, Piot and Missonier-Piera (2009) investigated the connection between the capital cost and institutional ownership of 102 French-listed companies.

H8: Institutional shareholding has a major influence on capital cost.

\section{Inflation Rate}

Capital costs are negatively related to inflation; an inflation increase leads to a rise in company 
revenue, and the company's capital cost drops (Khan \& Raffique, 2013). It means that as much the inflation raised, it leads to the high sale for the corporation, which will lead to the lower need of cost of capital which lowered the cost of capital. Cohen and Hassett (1999) suggested that with the low inflation rate in the United States in 1999, the cost of capital grew considerably. It indicates that the researcher has discovered a negative link between inflation and the cost of capital. As inflation rises, the cost of capital decreased. Whereas some researchers found positive relation of inflation with the cost of capital, for example, Effendi and Agustini (2017) found a positive relationship of inflation with the cost of capital.

H9: The inflation rate has a major impact on capital cost.

\section{Economic Growth}

Apergis and Eleftheriou (2012) analyze the dynamic connection between capital costs and macroeconomic variables (economic growth) for the 1996-2009 collection of newly formed markets. According to empirical evidence, macroeconomic factors (economic growth) have substantial effects on capital costs in emerging economies (Graham \& Harvey, 2001) think macroeconomic problems affect finance costs in developing economies.

H10: The cost of capital is affected by economic growth.

\section{Research Methodology \\ Population and Sample}

The study looks at Pakistan's non-financial industry. The study sample is made up of a balanced data set of businesses registered on the Pakistan stock market between 2008 and 2018. The study sample population comprises 175 companies (non-financial firms) out of 590 firms (excluding financial firms). The first sample of this study covers all Pakistani stock exchange businesses. Due to their distinctive characteristics, all financial sector organizations (such as banks, insurance providers, stock and real estate portfolios, and so on) are excluded from the study.

They have their corporate governance regulations and practices and are externally audited by monitoring agencies. Because financial firms' capital structures differ from those of non-financial organizations, the analysis excludes all financial firms, including investment firms, insurance companies, and banks, from the dataset. Second, the study eliminates companies that are in the process of merging or acquiring another business (M\&A). Third, the dataset eliminates businesses that were de-listed in Pakistan and companies for whom full data for the time covered by the study were not available. So the firms that were de-listed or combined during the research period (2008-2018) were omitted in this study. Finally, firms with incomplete records, either on the database or in annual reports, are removed.

In addition, firms by less than two years of observations per survey have not been considered to fulfill the panel data regression requirements (Stock \& Waston 2011); in addition, all companies with less than two observations have been removed because of the inclusive industry derived variables (Stock \& Waston, 2011). Finally, the study builds on 175 non-Pakistan Bursaries in a well-balanced dataset.

\section{Source of Data}

All the data related to the corporate governance variables were gathered from the Annual reports of corporations. All the data associated with the macroeconomic variables were collected from the Economic Survey of Pakistan and World Development Indicators.

\section{Model Specifications}

The panel data method is used in this analytical analysis. Brooks (2008) defines panel data analysis as used where a sample contains both time series and cross-sectional components, such as when analyzing several topics (for example, firms) over time. This thesis presents two types of 
information: a) cross-sectional data reflected in the numerous variables reflecting basic features of Pakistani firms understudy and b) time series (eleven-year period) information reflects changes among the companies analyzed throughout time. The analysis primarily employs GMM.

The Generalized Technique of Moments is a dynamic panel approach that considers the influence of past controlled disclosures on the present one. It makes use of a sample with a short period but a large number of companies. Arellano and Bover (1995) and Blundell and Bond (1998) created GMM to increase the efficiency of Arellano and Bond's original difference GMM (1991). Generally, when dealing with short-sample periods, autocorrelation, heteroscedasticity, heterogeneity, and endogenous and specified explanatory variables, the GMM method offers significant advantages. As a result, the estimation's efficiency considerably improves. The GMM estimator's ability to produce impartial, trustworthy, and efficient findings relies on the usage of proper tools. As a result, there are three diagnostic tests available: the Hansen/Sargan overidentification restriction test, AR (2), and the Hansen difference test. To examine the overall rationality of the instruments, the Sargan test of over-identifying constraints assesses the sample analog of the moments conditions used in the estimation method. The tool is valid, and the model is properly defined if the moment condition is met. AR (2) then runs a residuals test to see if the revised error terms are serially linked. Third, using the GMM method, the difference in the Hansen test is used to examine the validity of extra moment conditions. The calculated model is supported by the inability to reject the three null hypotheses. The rejection of the three null hypotheses supports the computed model.

\section{Cost of Capital}

The weighted average capital cost is the amount of money that a company should pay for full capital. Capital cost refers to the entire amount of stock and debt held by a company. The cost of capital was used to assess corporate governance procedures as independent variables as a dependent variable in the study. Capital cost is a crucial part of the development of wealth. The best capital structure for practitioners and researchers combines capital costs with shareholder wealth and capital costs (Afkhami Rad, 2014).

A weighted average capital cost was the most commonly utilized cost-estimation approach in real-time (Massari et al., 2008). The average weighted cost of capital was the amount of equity and capital cost. The weighted average capital cost has become a fundamental idea in corporate finance due to these advantages (Farber et al., 2007). The weighted total capital cost was used as an adjunct to the company's capital cost (Bozec \& Bozec, 2010). According to Massari et al., (2008), the weighted average cost of capital technology is still frequently used for research throughout the whole globe.

\section{Weighted A verage Cost of Capital}

According to the quality of corporate governance, all non-financial corporations on the Pakistan Stock Exchange need to improve their capital costs. Internal corporate governance was handled with the cost of capital as the dependent variable as independent variables in this study. The research estimates the capital cost using the weighted average capital cost.

The weighted average capital cost is the amount of money a company should pay to obtain full investment. The total amount of shares and debt of a company is called capital cost. As a dependent variable in the study, capital costs were used for an indigenous assessment of the effect of corporate governance. Capital costs are a vital element in the creation of wealth. WACC is a proxy to establish the costs of capital for a firm (Bozec \& Bozec, 2011). According to Massari (2007), the WACC technique is still frequently used in studies around the world,

$\mathrm{WACC}=\mathrm{Wd} \mathrm{Rd}(1-\mathrm{Tc})+\mathrm{WeRe}$ 
The WACC Equation employs both equity and debt. Rd denotes the burden of interest on the firm's unpaid debt, where Re represents the equity cost. It is usually computed using the Price model of Capital Assets (CAPM). Wd and We are debt and equity weights, respectively.

Debt weights are the debt-to-debt and equity ratio. The weight of equity is measured as the equity-to-debt-plus-asset ratio multiplied by the equity-to-debt- Tc indicates the corporate income tax rate. The usual treatment is used in this computation (1-tc), reflecting the deductibility of interest payments. As a result, debt interest costs will decrease (Rad, 2014).

\section{Cost of Equity}

Various ways of determining capital costs are employed. On the other hand, the Capital Asset Pricing Model is frequently used in the literature and acknowledged (Chen, 2009; Da, 2012). In financial textbooks, Sharpe and Lintner's CAPM are suggested for capital cost estimations. CAPM is used to assess the capital cost and portfolio efficiency in applications all over the world (Fama \& French, 2004). This approach thus uses CAMP to determine capital cost.

$\overline{\mathrm{R}}$ it $=\mathrm{RFR}+(\mathrm{Rm}-\mathrm{RFR}) \beta$

$\overline{\mathrm{R}}$ is the cost of capital of the firm I at time $t$ in this case. RFR is an abbreviation for the risk-free rate. $\mathrm{Rm}$ represents the market rate of return. $\beta$ indicates market sensitivity.

\section{Beta Model}

$\beta=$ CoVar of Market \& Stock Returns/Var of Market return Here: CoVar is the correlation between market and stock returns Var denotes the market return variation.

\section{Cost of Debt}

The cost of lending is the interest rate that firms charge on long-term loans. To put it another way, the interest cost is the amount paid for the company's loans. If this information is unavailable, it is commonly recommended that the interest paid on long-term loans be used to balance the cost of debt. On the other hand, the loan cost is frequently calculated using the interest rate on a risk-free bond.

\section{Econometric Model}

Where;

$$
\begin{aligned}
\text { WACC }_{i t}=\beta_{0} & +\beta_{0} \text { WACC }_{t-1}+\beta_{1} \text { BS }_{i t}+\beta_{2} \text { BINDP }_{i t}+\beta_{3} \text { CDUAL }_{i t}+\beta_{4} \text { COMIT }_{i t} \\
& +\beta_{5} \text { POLCON }_{i t}+\beta_{6} L E V G_{i t}+\beta_{7} \text { SIZE }_{i t}+\beta_{8} \text { INSTI It }_{i t}+\beta_{9} I_{t} L_{t} \\
& +\beta_{10} \text { EGROW }_{t}+\epsilon_{i t}
\end{aligned}
$$

WACC $=$ cost of capital

$\mathrm{BS}=$ number of board directors

$\mathrm{BINDP}=$ is the proportion of independent board members to overall board size.

CDUAL $=$ is a dummy variable with a value of 0 if the CEO and chairman roles are separated and one otherwise.

COMIT $=$ number of board committees

$\mathrm{LEVG}=$ leverage debt/assets

$\mathrm{SIZE}=$ firm size

$\mathrm{INFL}=$ inflation rate

EGROW = Economic growth rate

POLCON=political connection is a dummy variable that proceeds the value of 1 if political connections exist. 


\section{Results and Discussion}

\section{Descriptive Statistics}

\begin{tabular}{cccccc}
\hline Variable & Obs & Mean & S.D. & Min & Max \\
& & & & & \\
\hline WACC & 1925 & 0.0917 & 0.318 & -6.49 & 0.575 \\
BS & 1925 & 8.10 & 1.62 & 5.00 & 15.0 \\
BINDP & 1925 & 0.562 & 0.270 & 0.000 & 0.941 \\
CDUAL & 1925 & 0.259 & 0.438 & 0.000 & 1.00 \\
COMIT & 1925 & 1.95 & 0.829 & 0.000 & 7.00 \\
PLCON & 1925 & 0.534 & 0.499 & 0.000 & 1.00 \\
LEVG & 1925 & 0.657 & 0.457 & 0.000 & 4.62 \\
SIZE & 1925 & 20.5 & 3.65 & 0.0569 & 27.3 \\
INSTI & 1925 & 0.0456 & 0.0683 & 0.000 & 0.514 \\
INFL & 11 & 0.093 & 0.604 & 0.0190 & 0.243 \\
EGROW & 11 & 0.0406 & 0.0118 & 0.0170 & 0.0579
\end{tabular}

Note: The table shows descriptive data for the non-financial sector of Pakistan, including mean, standard deviation, lowest value(Minimum), and the highest value(maximum).

\section{Correlation}

\begin{tabular}{|c|c|c|c|c|c|c|c|c|c|c|c|}
\hline & $\begin{array}{l}\text { WAC } \\
\text { C }\end{array}$ & BS & BINDP & $\begin{array}{l}\text { CDUA } \\
\mathbf{L}\end{array}$ & $\begin{array}{l}\text { COMI } \\
\mathbf{T}\end{array}$ & $\begin{array}{l}\text { PLCO } \\
\mathbf{N}\end{array}$ & $\begin{array}{l}\text { LEV } \\
\text { G }\end{array}$ & SIZE & INSTI & $\begin{array}{l}\text { INF } \\
\text { L }\end{array}$ & $\begin{array}{l}\text { EGR } \\
\text { OW }\end{array}$ \\
\hline WACC & 1 & & & & & & & & & & \\
\hline BS & -0.03 & 1 & & & & & & & & & \\
\hline BINDP & -0.007 & 0.154 & 1 & & & & & & & & \\
\hline $\begin{array}{l}\text { CDUA } \\
\mathrm{L}\end{array}$ & -0.033 & -0.141 & -0.118 & 1 & & & & & & & \\
\hline COMIT & 0.01 & 0.327 & 0.056 & -0.084 & 1 & & & & & & \\
\hline PLCON & 0.079 & 0.086 & 0.039 & -0.127 & -0.011 & 1 & & & & & \\
\hline LEVG & -0.243 & 0.004 & 0.019 & 0.119 & -0.092 & 0.071 & 1 & & & & \\
\hline SIZE & 0.051 & 0.062 & 0.062 & -0.048 & -0.016 & 0.067 & 0.025 & 1 & & & \\
\hline INSTI & 0.053 & 0.084 & 0.104 & 0 & -0.089 & 0.098 & 0.004 & 0.104 & 1 & & \\
\hline INFL & 0.046 & -0.014 & 0.147 & -0.02 & -0.298 & 0.036 & -0.035 & 0.304 & 0.207 & 1 & \\
\hline $\begin{array}{l}\text { EGRO } \\
\mathrm{W}\end{array}$ & -0.054 & 0.015 & -0.159 & 0.016 & 0.307 & -0.037 & 0.029 & -0.312 & -0.213 & 0.05 & 1 \\
\hline
\end{tabular}


Note: table presents the correlation of the non-financial sector of Pakistan. Correlation analysis analyzed no multicollinearity issues in panel data of 11 years of

Non-financial sector because values relay below the 0.9 correlation outcomes described the significant correlations all the values have below 0.9

\section{GMM results}

\begin{tabular}{lll}
\hline Variable & Coefficients & p-Value \\
\hline L.WACC & 0.0943375 & 0.000 \\
BS & $-\underline{0.0040161}$ & $0.053^{*}$ \\
BINDP & $-\underline{0} .0228279$ & $0.088^{*}$ \\
CDUAL & $-\underline{0.0168616}$ & $0.076^{*}$ \\
COMIT & 0.0087864 & 0.116 \\
PLCON & $-\underline{0.0178036}$ & 0.886 \\
LEVG & 0.0282287 & 0.278 \\
SIZE & 0.0033759 & 0.641 \\
INSTI & 0.5900547 & $0.068 *$ \\
INFL & $-\underline{0.1638393}$ & $0.068 *$ \\
EGROW & 0.4529219 & 0.278 \\
F-stat & & 32.52 \\
Sargan (P Value) & & 0.132 \\
Hansen (P Value) & & 0.675 \\
AR(2) P Value & & 0.425 \\
\hline
\end{tabular}

The table displays the system GMM results for Pakistan's non-financial sector. The Hansen test results demonstrate that all of the instruments used in the study are valid, and the Arellano-bond test for AR (2) in the table clearly shows that there is no autocorrelation of error terms.

At the $10 \%$ level of significance, the study's findings demonstrate that board size has an adverse and significant effect on the cost of capital in Pakistan's non-financial sector. This finding suggests that when board size increases, the cost of capital in Pakistan's non-financial sector lowers. According to resource dependence theory, the greater the size of a company's board of directors has a negative relationship with its cost of capital. There is a negative association between board size and the cost of capital. It suggests that the size of boards of directors may suffer cheaper capital expenditures in Pakistan than those with smaller boards (Arslan \& Abidin, 2019).

The study's findings demonstrate that board independence significantly negatively influences the cost of capital in Pakistan's non-financial sector. This finding suggests that having an independent board of directors reduced the cost of capital in Pakistan's non-financial sector. As a result, we accepted Hypothesis 2 since it shows that board independence has a significant impact on the cost of capital. This data confirms the reputation hypothesis offered by Ashbaugh et al. (2004), which states that the cost of capital is negatively related to the board's independence.

Furthermore, the CEO duality has a negative and significant association with the cost of borrowing. This study suggests that CEO duality reduced the cost of capital in Pakistan's nonfinancial sector. The fact that the chairman or a board member is also the CEO, according to the resource dependency hypothesis, may lessen the quantity and variety of resource linkages outside the business. As a result of duality, a strong leadership structure lowered the cost of capital (Doan $\&$ Acar, 2020). As a result, we accepted hypothesis 3 since hypothesis 3 shows that CEO duality has a considerable impact on the cost of capital.

Similarly, the connection between the Board committees and the cost of capital is insignificant. According to this research, CEO duality does not influence the cost of capital in Pakistan's non- 
financial industry. As a result, we rejected hypothesis 4, which asserts that Board committees have a significant impact on the cost of capital. Furthermore, the political and non-political have insignificant on the cost of capital. This conclusion suggests that both political and non-political variables have no impact on the cost of capital in Pakistan's non-financial sector. As a result, hypothesis 5 rejected. According to hypothesis 5, political and non-political factors have a substantial impact on capital costs.

Furthermore, the link between the cost of capital and leverage is insignificant. This result suggests that leverage does not affect the cost of capital in Pakistan's non-financial sector. As a result, hypothesis 6 rejected. Leverage, as indicated in, has a major impact on the cost of capital.

Furthermore, the firm's size has a minimal association with the cost of financing. This study suggests that the size of the business does not affect the cost of capital in Pakistan's non-financial sector. As a result, hypothesis 7 rejected. As indicated in hypothesis 7, the size of the business has a significant impact on the cost of capital.

As a result, institutional ownership has a significant and positive association with capital costs. This result implies that the cost of capital in Pakistan's non-financial sector raised as institutional ownership raised. As a result, hypothesis 8 rejected, which asserts that institutional ownership has a significant impact on the cost of capital.

Furthermore, the rate of inflation has a significant and negative link with the cost of capital. This finding indicates that the cost of capital in Pakistan's non-financial sector would fall when the inflation rate rises. As a result, hypothesis 9 accepted. As stated by hypothesis 9 , the inflation rate has a major influence on the cost of capital. Furthermore, the rate of economic growth is inversely proportional to the cost of capital. This finding implies that the economic growth rate does not affect the cost of capital in Pakistan's non-financial sector. As a result, hypothesis 10 rejected because hypothesis 10 shows that the rate of economic growth significantly impacts the cost of capital.

\section{Conclusions and Recommendations}

The objective of this study was to examine the impact of corporate governance on the cost of capital in Pakistan's non-financial sector. The study analyzed a sample of 175 non-financial corporations listed on the Pakistan stock market for 11 years (2008-2018). The impact of corporate governance on the cost of capital has risen in relevance for shareholders, practitioners, and government regulators. This work adds to the body of knowledge in two ways. Furthermore, this study is required for two reasons. 1) This is Pakistan's first study of the composition of corporate governance variables, firm-specific factors, and country-specific factors. 2) One of the most wide-ranging data sets on corporate governance in Pakistan (a sample of 175 Pakistani nonfinancial sector firms from 2008 to 2018). GMM was used in the analysis for the study's estimation. According to this study, the board size, CEO duality, board independence, and inflation are negatively and significantly related to the cost of capital; it means that when the board size, CEO duality, board independence, and inflation increased, the cost of capital decreased in Pakistan's non-financial sector. Furthermore, board committees, political connections, company leverage, and economic growth do not affect the cost of capital in Pakistan's non-financial sector. In comparison, an increase in institutional shareholding increased the cost of capital in Pakistan's non-financial sector.

\section{References}

Afza, T., \& Mirza, H. H. (2011). Institutional shareholdings and corporate dividend policy in Pakistan. African Journal of Business Management, 5(22), 8941-8951.

Apergis, N., \& Eleftheriou, S. (2012). The Role of Macroeconomic Factors in Explaining the 
Cost of Capital: Evidence from a Group of Emerging Economies. Asian journal of fiancne and accounting, 4(1), 313-329.

Ahmed, H., \& Javid, A. Y. (2008). Dynamics and determinants of dividend policy in Pakistan (evidence from Karachi stock exchange non-financial listed firms).

Ahmed, $\mathrm{H}$ and Javid, A 2009, "Dynamics and Determinants of Dividend Policy in Pakistan(Evidence from Karachi Stock Exchange Non-Financial Listed Firms), International Research Journal of Finance and Economics-, ISSN 1450-2887, Issue 25.

Ali Shah, S. Z., \& Butt, S. A. (2009). The impact of corporate governance on the cost of capital: empirical evidence from Pakistani listed companies. The Lahore Journal of Economics, 14(1), 139-171.

Al-Malkawi, H.-A. N., et al. (2012). Internal mechanisms of corporate governance and firm performance: a review of theory and empirical evidence. Journal of Modern Accounting and Auditing, 8(4): 549.

Arora, A., \& Sharma, C. (2016). Corporate governance and firm performance in developing countries: evidence from India. Corporate governance, 16(2):420-436.

Arslan, M., \& Abidin, S. (2019). Nexus between corporate governance practices and cost of capital in PSX listed firms. Cogent Economics \& Finance, 7(1), 1600222.

Ashbaugh, H., et al. (2004). Corporate governance and the cost of capital-capitat." Emory, University of Iowa. Retrieved on January 26: 2006.

Awan, H. M., Bukahri, K. S., Ansari, R. M., \& Zakariya, B. (2011). Corporate governance practices and their impact on firm's capital structure and performance; case of Pakistani textile sector. Proceedings 8th AFC sames Samos, 1, 390-400.

Azam, M., Usmani, S., \& Abassi, Z. (2011). The impact of corporate governance on firm's performance: Evidence from Oil and Gas Sector of Pakistan. Australian journat Journal of basic and applied science, 5(12), 2978-2983.

Becht, M., et al. (2003). Corporate governance and control. Handbook of the Economics of Finance, Elsevier. 1, 1-109.

Beiner, S., Drobetz, W., Schmid, M. M., \& Zimmermann, H. (2006). An integrated framework of corporate governance and firm valuation. European Financial Management, 12(2), 249283.

Bhatt, P.R. and Bhatt, R.R. (2017), Corporate governance and firm performance in Malaysia, Corporate Governance: The international International Journal of Business In Society, 17 (5), 896-912.

Bliss, M. A. and F. A. Gul (2012). Political connection and cost of debt: Some Malaysian evidence. Journal of Banking \& Finance, 36(5): 1520-1527.

Blom, J. (2009). CHAPTER FIVE CORPORATE GOVERNANCE AND THE COST OF DEBT JASPER BLOM, MARC BJ SCHAUTEN. New developments in financial modelling, 116.

Botosan, C. A., \& Plumlee, M. A. (2002). A re-examination of disclosure level and the expected cost of eapital-capital. Journal of accounting research, 40(1), 21-40

Boubakri, N., Guedhami, O., Mishra, D., \& Saffar, W. (2012). Political connections and the cost of equity capital. Journal of corporate finance, 18(3), 541-559

Bradley, M., \& Chen, D. (2015). Does board independence reduce the cost of debt?. Financial Management, 44(1), 15-47.

Braga-Alves, M. V. and K. Shastri (2011). "Corporate governance, valuation, and performance: evidence from a voluntary market reform in Brazil." Financial Management 40(1): 139157.

Bulathsinhalage, S., \& Pathirawasam, C. (2017). The effect of corporate governance on firms' the capital structure of listed companies in Sri Lanka. Journal of Competitiveness, 9(2).

Butt, S. A., \& Hasan, A. (2009). Impact of ownership structure and corporate governance on the capital structure of Pakistani listed companies. International Journal of Business \& Management, 4(2). 
Cohen, D., \& Hassett, K. A. (1999). Inflation, taxes, and the durability of capital. National Tax Journal, 52(1), 91-98.

Core, J. E., et al. (1999). Corporate governance, chief executive officer compensation, and firm performance. Journal of financial economics 51(3): 371-406.

Doğan, B., \& Acar, M. (2020). The impact of corporate governance on the cost of capital: an application on the firms in the manufacturing industry in Borsa Istanbul. CES Working Papers, 12(1), 65-88.

Effendi, R., \& Agustini, A. T. (2017). IFRS Adoption and Cost of Capital.

Faccio, M. (2006). Politically connected firms. American economic review, 96(1), 369-386.

Goodstein, J., Gautam, K., \& Boeker, W. (1994). The effects of board size and diversity on strategic change. Strategic management journal, 15(3), 241-250.

Hajiha, M. \& M. G. Farhani (2012). An investigation on the relationship between internal audit quality and economic value added: evidence from Iran. J Basic Appl Sci Res 2: 6872-6881.

Houston, J. F., Jiang, L., Lin, C., \& Ma, Y. (2014). Political connections and the cost of bank loans. Journal of Accounting Research, 52(1), 193-243.

Ilyas, M., \& Jan, S. (2017). Corporate Governance and Cost of Capital: Evidence from Pakistan. Global Management Journal for Academic \& Corporate Studies, 7(2), 10-21.

Javid, A. Y., \& Iqbal, R. (2008). Ownership concentration, corporate governance and firm performance: Evidence from Pakistan. The Pakistan Development Review, 47(4-II), pp. 643-659.

Jensen, M. C. and W. H. Meckling (1976). Theory of the firm: Managerial behavior, agency costs and ownership structure. Journal of financial economics, 3(4): 305-360.

Kajananthan, R. (2012). Effect of corporate governance on capital structure: case of the Srilankan listed manufacturing companies. Researchers World, 3(4), 63.

Khan, K., and Rafiq, M. Inflation, Stock Prices and Cost of capital, Malaysia, June 2013. 3rd International Conference on Management, Economics and Social Sciences (ICMESS').

La Porta, R., et al. (2002). Investor protection and corporate valuation. The journal of finance 57(3): 1147-1170.

Letza, S., et al. (2004). Shareholding versus stakeholding: A critical review of corporate governance. Corporate Governance: An International Review, 12(3): 242-262.

Lorca, C., Sánchez-Ballesta, J. P., \& García-Meca, E. (2011). Board effectiveness and cost of debt. Journal of business ethics, 100(4), 613-631.

Massari, M., Roncaglio, F., \& Zanetti, L. (2008). On the equivalence between the APV and the WACC approach in a growing leveraged firm. European Financial Management, 14(1), 152162.

Mehar, A. (2005). Corporate governance and dividend policy. Pakistan Economic and Social Review, 93-106.

Mir, S. and M. Nishat (2004). Corporate Governance Structure and firm performance in Pakistan: An empirical study. Second Annual Conference in Corporate Governance. Lahore University of Management Sciences, Lahore.

Mirsharafoddini, H. S., Farhani, M. G., Hajiha, Z., Yahaghi, E., Honarvar, M. S., Khodaverdi, E., ... \& Tousi, E. F. (2014). Characteristics of board of directors and creating Economic Value Added: Evidence from Iran. International Journal of Current Research and Academic Review, 2(3), 149-162.

Mishra, S., \& Mohanty, P. (2014). Corporate governance as a value driver for firm performance: evidence from India. Corporate Governance,14(2),265-280.

Nguyen, D. V., \& Nguyen, L. T. N. (2017). Impact of Corporate Disclosure on Cost of capital Capital in Vietnam. International Journal of Financial Research, 8(4), 64-70.

Öztürk, M. B., \& Demirgüneş, K. (2008). Kurumsal Yönetim Bakişaçisiyla Entellektüel Sermaye. Selçuk Üniversitesi Sosyal Bilimler Enstitüsü Dergisi, (19), 395-411.

$\mathrm{Rad}$, S.A. (2014). The relationship between corporate governance practices and cost of capital in 
large listed companies of New Zealand and Singapore. Retrieved http://researchcommons.waikato.ac.nz/.

Rehman, M. A., Rehman, R. U., \& Raoof, A. (2010). Does corporate governance lead to a change in the capital structure. American Journal of Social and Management Sciences, 1(2), 191-195.

Shleifer, A. and R. W. Vishny (1997). A survey of corporate governance. The journal of finance 52(2): 737-783.

Sun, W., et al. (2011). Introduction: rethinking corporate governance-lessons from the global financial crisis. Corporate governance and the global financial crisis, Cambridge University Press: 1-22.

Tariq, Y. B., \& Abbas, Z. (2013). Compliance and multidimensional firm performance: Evaluating the efficacy of rule-based code of corporate governance. Economic Modelling, 35, 565-575.

Ujunwa, A. (2012), "Board characteristics and the financial performance of Nigerian quoted firms", Corporate Governance: The International Journal of Business in Society, 12 (5), 656-674.

Wong, W.-Y. and C.-W. Hooy (2018). Do types of political connection affect firm performance differently? Pacific-Basin Finance Journal 51: 297-317.

Yang, T., \& Zhao, S. (2014). CEO duality and firm performance: Evidence from an exogenous shock to the competitive environment. Journal of Banking \& Finance, 49, 534-552.

Yasser, Q. R., et al. (2011). Corporate governance and firm performance in Pakistan: The case of Karachi Stock Exchange (KSE)-30. Journal of economics and international finance 3(8): 482-491.Yawson, A. (2006). Evaluating the characteristics of corporate boards associated with layoff decisions. Corporate Governance: An International Review, 14(2), 75-84. 